\title{
Issues of Foreign Language Learning Through Formulaic Language Translation
}

\author{
Jolita Horbacauskiene \\ Lukas Volskis \\ Kaunas University of Technology, Lithuania
}

Doi: $10.19044 / 11 c . v 6 n o 2 a 5$

URL:http://dx.doi.org/10.19044/1lc.v6no2a5

\begin{abstract}
Formulaic language acts as an important part of our language which is reflected in the use of multi word units such as collocations, idioms, proverbs or other expressions. The use of those elements is mostly referred to maintaining our social interactions for communication purposes. The aim of this paper is to analyse translation procedures of formulaic language elements from the source language to the target language and disclose the challenges and advantages of such assignments for foreign language learning.
\end{abstract}

Keywords: foreign language learning, Formulaic language sequences, translation assignments.

\section{Introduction}

Formulaic language acts as an important part of our language which is reflected in the use of multi word units such as collocations, idioms, proverbs or other expressions. The use of those elements is mostly referred to maintaining our social interactions for communication purposes. Combinations of words, such as fixed phrases or idiomatic expressions are considered to be formulaic. Numerous studies revealed that formulaic language has an immeasurable impact to the processes of acquiring, learning and producing the language. Despite the fact that until now this area is still considered as developing it is agreed that mainly formulaic language focuses on how words tend to group together and while being in units, operate as single wholes. The instances of formulaic language are frequent in the text of popular science texts if compared to any other kind of scientific texts where the vocabulary is less expressive. A number of studies conducted on formulaic language elements focused on the frequently they tend to occur, in which linguistic discourses they were found most commonly and what problems the learners of foreign language faced while dealing with them. This paper 
analyses what translation strategies are taken into consideration by a translator when doing the translation in the discourse of popular science texts.

\section{Formulaic Sequences and their Functions}

Texts are compiled of a large number of multi word sequences, in which some of the words co-occur with other ones and they form fixed word combinations. This phenomenon is referred to as formulaic language, and each individual case of it is called a formulaic sequence. According to Wood (2010) "formulaic sequence is a sequence of words or other meaning elements, which is, or appears to be, prefabricated. It is, stored and retrieved whole from memory at the time of use, rather than being subject to generation or analysis by the grammar of the language". Usually formulaic sequences are found in the forms of collocations, idioms, proverbs or sayings - despite the fact, that those units consist of more than one word, they operate as single wholes. Schmitt (2004) states that there might be some difficulties developing a comprehensive definition of formulaic language due to the fact that examples of it exist in many different forms, and, they are diverse, so it remains one of the main problems in this area of linguistics, while Moon suggests to define this phenomenon as "multi-word items" (2011, p. 44). Formulaic language facilitates efficient language processing from the perspective of two modes, namely - processing word sequences as single units and analysing them into smaller segments based on grammatical rules. Another aspect which should be taken into account, is that formulaic language is ubiquitous: at least $55 \%$ of the words in an English text form parts of prefabricated multi-word units (Hsu, 2014). Despite the prevalence of formulaic language, there are many disagreements about which sequences and multi word units are considered formulaic. As mentioned before, idioms, phrasal verbs, set phrases, proverbs and proper names are relatively fixed word sequences and they reflect one aspect of formulaic language. On the other hand, lexical bundles are also considered as subgroups of formulaic language, since they are recurrent word combinations. As Schmitt (2004) states diversity remains one of the main reasons why it is difficult to draw explicit definition of formulaic sequences. They are commonly used for different purposes: to express a message or an idea, function, or to transact specific information in a precise and understandable way. The term formulaic sequence covers a wide range of phraseology, but, as mentioned above, since there is much diversity in this field, there is no absolute criterion by which those sequences could be defined.

One common type of function that is often realised by formulaic sequence is to maintain social interaction employing light conversations to pass the time. The content of conversation becomes less important that the whole process of communication. During this process, people usually rely upon sets of conversationalized phrases, which do not impose any personal 
life issues and just let the conversation flow. Another specific function of formulaic sequences is the realisation of the discourse organisation. Sometimes the purpose of using those sequences is to transact information in precise and efficient manner. Scientific words in this discourse accomplish this purpose, but it does not mean that scientific dictionary is ought to be limited into single words. The specific type of scientific formulaic sequences is likely to be prevalent in scientific discourse, as Wray (2002) states, there are numbers of other purposes that formulaic sequences accomplish. Because of the fact, that formulaic sequences are frequently used in language, they act up as not important only to efficient, but also to appropriate use of language.

\section{Translation Issues of Formulaic Sequences}

When translating into English, there are many obstacles that translators deal with: complex sentences, specific terminology, unknown words in the source text. First, if source and target languages have sentences with different syntactical and lexical features, they have to be completely clear, or, in other words, become readable and comprehensible. It may be achieved by choosing appropriate meaning and forms of words. Secondly, technical and/or scientific text has to be concise. Conciseness might be described as a phenomenon, which improves the basic organisation of original document. Poorly organised document will not let the reader smoothly go through the text. It can be improved by omitting unnecessary words, which do not contribute to the meaning. By doing that, the translator must ensure that every idea remains included and transferred from the original. Lastly, the translation has to be correct. The phenomenon of correctness can be described in two ways - the accurate rendering of the main ideas and terminology from source to target language and to produce an accurate document in the target language despite any mistakes and inaccuracies in the source document.

One more aspect of technical vocabulary that should be taken into account when translating is a distinction between technical and descriptive terms. The writer of a source language could use a descriptive term when writing about technical objects as based on Newmark (1988) pointed three main reasons to explain this: the object is new and yet there is no name to describe it; the descriptive term is used as a familiar alternative seeking to avoid repetition; the descriptive term is used in order to make a contrast with another term.

Usually the translator takes into account technical and descriptive terms according to their counterparts, and, avoids showing his or her personal knowledge by translating a descriptive term according to a meaning of a technical term. However, in such instances when descriptive terms in source language are being used because of the fact, that appropriate terms do not exist, or the object might seem to be unknown to the audience, then the translator is 
ought to translate a descriptive term by a technical term. It is agreed, that technical terms are more precise, clear and more narrow semantically if compared to descriptive terms, so it could be argued that maintaining this kind of preciseness will help the reader to feel more comfortable when reading, or even going quickly through the text in the cases of looking for specific information. On the other hand, descriptive terms could serve various communicative purposes, e.g. when a technical term is rare, or there is a lack of it in the dictionary of a source language.

Technical texts, according to Wright et al. (1993) are considered to be special language texts as they include not only specific terminology, but also require certain knowledge and understanding of the subject field. Translators of such texts are usually highly trained linguists, who develop specialised skills in specific technical or scientific areas.

When analysing scientific discourse of a collocation, it is important to mention, that there are no specific terminology or specialised collocations that could possibly include different combinations of verbs, adjectives, adverbs or nouns. When a translator has to deal with identifying this kind of register, it becomes very important to render such instances into accurate and natural equivalents, in order to make that specific scientific topic understandable to a non-specialised audience. The process of identifying might be a challenge, because until now multi word terms and collocations consisting of noun-noun or adjective-noun are not strictly distinguished. Consequently, each word combination, which can be recognised as a technical collocation, requires certain knowledge to analyse a particular combination is an example of one exact concept, and which is a substitute example of a related concept. Heid (2001, p. 788-9) developed four main principles that could be helpful to identify and analyse collocations: every collocation involves two lexemes and one of them two must be a term, which probably has a conceptual description; elements of a collocation could be collocations themselves, especially if there is an instance of such collocation: (adjective + noun = collocation) + verb; most of European languages have collocational categories for two lexemes, based on noun + noun, noun + adjective, noun + verb, adverb + adjective, verb + adverb structure; a relationship between components of a collocation exist when one lexeme is a base (determined element), while the other is collocate (determining element).

One more approach proposed by Manning and Schutze (1999, p. 1723 ), is a three-criteria- system: non-compositionality, non-substitutability, and non-modifiability. The first criterion refers to the fact that the meaning of a collocation could not be compared as equal to the meanings of its separate parts. The second criteria of non-substitutability states that none of collocation components can be replaced with synonyms. And, finally, the last criteria of 
non-modifiability states that collocations cannot be freely modified by adding lexical material or transforming them grammatically.

When discussing the translation problems of collocations, the issues raised by Baker (1992) should be taken into account: as long as a collocation is found in the target language, and it conveys the same or a similar meaning to the one from source language, the translator will not get confused; in the source text, a collocation may be easily misinterpreted due to the interference from translator's native language. This occurs in such cases when a collocation corresponds in form to a common collocation in the target language; when rendering unmarked collocations from source language into native language, the translator usually aims at producing a collocation which will be typical in his /her language, and at the same time, he or she will preserve the meaning associated with the source language collocation. The problem is that this aim cannot be always accomplished: there is always tension between choosing what is typical, and what is accurate. The nearest suitable collocation in the target language will often involve some shifts in the meaning. Those shifts may be slight or they can be significant. The significance of those meaning differences result in producing inaccurate translation, consequently there are smooth translations, which sound like original, and the ones, which may seem clumsy and sound foreign; collocations, which reflect the cultural setting in which they occur when texts are based on different cultural contexts, in the source text there will be examples of collocations that convey some unfamiliar meanings and ideas to the target reader. Like words, which are culturally specific, those collocations refer to some concepts, which will not be easily understandable to the target reader. It is unavoidable, that there will be a partial increase of information, because unfamiliar ideas cannot be easily introduced in the target text without providing some more accurate information, but, on the other hand, the translator does not have to reproduce whole amount of information, that he has in the source text; in order to create or convey new images, uncommon word combinations are used in the source text. Preferably, the translation of a marked collocation will be consequently marked in the target text. The reader will be alerted with the writers wish to communicate indirectly, writing words in bold font or marking them with commas, but in the target text the translator will most likely highlight those words.

As far as idioms are concerned, the first obstacle that the translator meets is the recognition of the idiom he or she is dealing with - it is never obvious because of the fact that there are various types of idioms and some of them are more easily recognisable than the other ones. Those easily recognisable are expressions, which violate truth conditions, e.g., it's raining cats and dogs, food for thought (Baker, 1992, p. 65). They also include expressions, which do not follow the grammatical rules, e. g. the powers that be, the world and his friend. Moreover, expressions, which have a word like 
at their beginnings, tend to be identified as the ones, which should not be translated or interpreted literally. In other words, the more difficult it becomes to understand the expression, the less sense it makes in a context given, and the more the translator will start recognising this unit as an idiom. It is strongly recommended to a translator, that, when translating a text full of idiomatic expressions, to have an access to monolingual dictionaries of idioms, and to be able to consult with native speakers of the language. In addition to this, Baker (1992) notes that most often there are two instances where an idiom might be easily misinterpreted, if a translator is unfamiliar with it. In order to translate an idiom correctly, the translator has to make sure, if he recognised and interpreted it correctly. Baker (1992) discusses four major problems that the translator has to face when translating idioms: when an idiomatic or fixed expression has no equivalent in the target language.; when an idiomatic or fixed expression has a similar counterpart in the target language, but may be used in a different context; when an idiomatic or fixed expression in the source text is used in its both - literal and idiomatic - meanings at the same time; during the process, when the use of idioms is conventionalized in written discourse, contexts where they can be used and the use of frequency becomes different in both source and target languages. Bassnett-McGuire argues that "translator, when putting the particular phrase into target language, should contend with the problem of the non-existence of a similar convention in target language culture" (1980, p. 21).

\section{Results and Discussion}

The texts representing a popular science register were chosen for the analysis. 165 sentences (in source and target languages respectively) were analysed and 345 occurrences of formulaic sequences were found and classified according to their types and translation strategies used.

The figure 1 represents the frequency of formulaic sequences in the analysed text in the source language, namely, collocations (52\%), idioms $(22 \%)$ were at significantly high rate of usage, phrasal verbs (14\%) and proper names $(12 \%)$ were found throughout the analysis. 


\section{Elements of formulaic language}

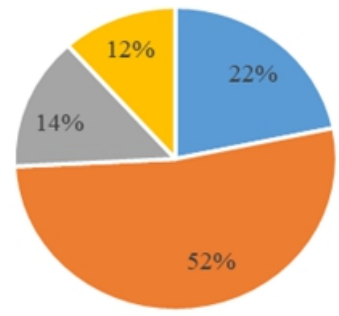

" Idioms (75) = Collocations (181) " Phrasal verbs (49) = Proper names (40)

When analysing the translation issues, there were 345 formulaic sequences classified according to their types and the translation strategy applied. Collocations made up most of the examples that were found. However, not many translation strategies were applied to formulaic language elements as literal and equivalent translation was performed in more than half of all instances. The analysis showed that paraphrasing when using related or unrelated word was applied on most of the instances. It might be due to the fact, that English and Lithuanian both have lexical differences and the collocational environments are particularly distinctive. When dealing with idioms, most of them were also translated literally or replaced by an equivalent, but there were considerable numbers of translation strategies applied on idioms and idiomatic expressions. Some of the cases revealed, that idioms with propositional meanings made some difficulties to the translator whether they were misinterpreted or translated literally without considering their referential or emotive meanings. The largest group of formulaic sequences found was collocations. They were translated mostly employing Baker's proposed taxonomy (translation by a more general word; translation by a more neutral or less expressive word; translation by paraphrase when using unrelated words; translation by paraphrase when using a related word; translation by omission; translation by illustration; equivalent and literal translation). Some examples are presented further:

There is the serious cost of time and effort spent foraging, hunting or cropping vegetation, time vulnerable to predators or competitors.

Maisto rinkimui, medžioklei ar derliaus nuèmimui reikia skirti daug daugiau laiko ir jègų, o ši laika savo naudai gali išnaudoti plèšrūnai ir konkurentai.

The example above contains an adjective collocation serious cost, what in Lithuanian refers to spending large amounts of assets. In the translated version the collocation is paraphrased into "reikia skirti daug daugiau laiko ir jegu", what is spending more time and money if back translated. The translaton strategy employed represents the paraphrase using unrelated words. 
The cost of living for a mammal in the cold is a hundred times that of a lizard. Žinduolio gyvenimo , squaudos “ šaltoje aplinkoje yra 100 kartu didesnès nei driežo.

This example represents the collocation cost of living, in English it referes to the financial everyday spendings while in the translated text "sqnaudos" is written in quotation marks because it refers and is used in different contexts, that is why the translator used illustration strategy in order to convey the original meaning in a metaphoric manner.

The obvious answer is niche expansion.

Atsakymas akivaizdus - kad galetume užimti teritorines ,,nišas”.

This example represents the strategy of translation by paraphrase when using a related word as niche expansion, is a verb collocation that in Lithuanian refers to the process of developing a certain field, but is translated into "teritorines nišas", that is expressed in a different lexical form and semantically it refers to a certain territory.

Another group of formulaic elements - idioms were also quire frequent in the texts under analysis. The biggest group (33) was translated employing translation strategies, literal translation was chosen also quite often (22) as well as equivalent translation (20). Below are some examples to illustrate:

For a long time, then, it was hard to tease out the origins of hot blood in the fossil record.

Ilgą laika iš iškastiniu suakmenèjusiu palaiku buvo sunku nustatyti šilto kraujo kilmę.

It can be noticed that expression to tease out figuratively refers to the process of separating hair by combing or separating facts from a great deal of information. It is translated as "sunku nustatyti" which is a general expression representing the core meaning, so strategy of choosing more general word was implied due to the lack of an equivalent in the target language.

The period came hot on the heels of the greatest mass extinction in the entire history of our planet, the Permian extinction, which is thought to have wiped out about 95 per cent of all species.

Šis laikotarpis, pasižymintis didžiausiu masiniu rūšiu išnykimu visoje mūsu planetos istorijoje - vadinamasis permo išnykimas, manoma, nušlave apie 95 \% visu rüšių.

One more example can be illustrated by employing the translation by a more general word. An idiom hot on the heels in English usually refers to following directly behind someone, but in the target language is translated into "pasižymintis", which means known, distinguished. The translator decided to generalize the sentence without transferring the idiomatic expression.

The long and short of it is that turbocharging the organs is not genetically difficult to do - it can be controlled by just a handful of genes - but it's 
energetically extremely costly, and will only be selected if the payback is worth it.

Trumpai tariant, ,„ikrauti“ organus energija genetiškai nèra sudètinga - tam pakanka nedaugelio genu, - tačiau energijos požiūriu tai labai brangu, vadinasi, atrankos büdu ši savybe gali büti ịtvirtinta tik tada, jei ji tikrai to verta.

Another example of choosing less expressive vocabulary is provided in the passage above. Idioms the long and short of it and payback is worth it that are replaced with equivalents in the translation will not get as much attention as the other one - a handful of, which refers to something or someone that is difficult to manage, but in the target text we have "nedaugelio", what may refer to a very small quantity or amount, so once again, the translation in this case sounds more neutrally and is less expressive, according to the vocabulary chosen.

How these lizards survived the Permian extinction is another question for another place.

Kaip šie driežai išgyveno permo išnykimo metu, yra atskiras klausimas, kurio čia nenagrinèsime.

The idiomatic expression containing figurative meaning another question for another place, in the target language is translated into "atskiras klausimas, kurio čia nenagrinèsime". Performing back-translation, it might sound like another question, which will not be discussed here. Although both variants are similar, but the second part of the expression was paraphrased and engaged in a different form than was the original.

For those who like mouth-filling terms, it's called 'inertial endothermy'.

Mègstantiems sąvokas, kurias tariant galima nusilaužti liežuvi, paminèsiu, kai tai vadinama inercine endotermija.

The idiomatic expression mouth-filling terms is paraphrased into "squokas, kurias tariant galima nusilaužti liežuvį". The following one in Lithuanian refers to something, what could be spelled very hardly. In the source language mouth-filling refers to impressive sentences or clumsy phrases. The perception of a thought remains the same, but the paraphrase was implied while employing different vocabulary because the source meaning is complex, and there is no equivalent in the target language.

Grab at a lizard and it will disappear in a flash, streaking to the nearest cover as fast as the eyes can see.

Paméginkite pačiupti drieža, ir jis akimirksniu išnyks iš akiu, pasislèpdamas po artimiausia priedanga.

The above example represents the strategy of omission where two idioms: in a flash and as fast as the eyes can see are translated in the target text in the following manner- the first one is replaced with an equivalent "akimirksniu". But the second one is omitted. As fast as the eyes can see refers 
to reacting very quickly. The option of equivalent was not considered, so the translator did not want to exaggerate the passage with adjectives and this idiom was omitted as a piece which is not important to the whole of the text.

For the analysis of translation of phrasal verbs some illustrations are presented below:

But according to a quietly significant paper that slipped into a quietly obscure journal, Ecology Letters, in 2008, the vegetarians may have a lot more to be smug about than I've given them credit for.

Tačiau jei tikètume gana svarbiu straipsniu, kuris 2008 m. pasirode gana nežymiame Ecology Letters žurnale, vegetarai turi kur kas dangiau kuo didžiuotis, nei maniau iki šiol.

A phrasal verb slip into is usually used to refer to putting clothes on quickly and easily, this time it is used in a different context: Lithuanian word "pasirode" means showed up, or in this case - was released. It may be presumed that in such instance when there is no equivalent the translator decided to convey the meaning while choosing more general word which covers the propositional meaning in the target language.

Maximal metabolic rate is all about getting oxygen out to the muscles, but at rest muscles contribute little to oxygen consumption

Didžiausia medžiagu apykaitos sparta susijusi su raumenu aprūpinimu deguonimi, tačiau ramybès būsenoje raumenys deguonies suvartoja nedaug.

Structural change in a sentence might lead to a totally different use of formulaic language elements (see example above), to get out usually refers to leaving or escaping, expressing some feeling, emotion or condition, producing or manufacturing something. In the target translation getting oxygen out stands for "aprüpinimu deguonimi", which belongs to different semantic field and if back-translated would refer to supplying, providing oxygen. Presumable, as the solution to paraphrase the phrasal verb was chosen but the whole sentence was paraphrased too without taking into consideration its propositional meanings.

In recompense we have the boon of staying up at night and hanging out in the cold.

Tačiau dèl to sugebame keltis naktị ir pakęsti šaltị.

Following strategies of paraphrasing with the use of unrelated words (example above), two phrasal verbs stay up and hang out in the illustrated examples are translated by replacing the first one with an equivalent while the second one was paraphrased, back-translated from the target text "pakessti salti" would refer to surviving the cold, while hanging out is more associated to spending time aimlessly, but not to, as listed here in the example, surviving extreme conditions. From this perspective it could be considered that paraphrasing was employed in order to convey the meaning in other words, which were more direct and less complex semantically. 
The only case more or less ruled out is meteorite impact; there's little evidence of an impact like the one that finally brought the curtains down on the long reign of the dinosaurs, nearly 200 million years later

Vienintelis veiksnys, daugiau ar mažiau atmestas, - tai meteorito poveikis, nes nèra pakankamai ịrodymu poveikio, panašaus i ta, kuris po $200 \mathrm{mln} . \mathrm{m}$. galiausiai lème dinozauru viešpatavimo pabaigą.

This example includes not only phrasal verbs, replaced by equivalents (ruled out, brought down), but also there is an idiom to bring the curtains down, which is also replaced by an equivalent: "leme pabaigq" and it refers to the same field as the source language idiom.

As for the translation of proper names, most frequently they were translated employing the strategy of preservation as well as they were localized due to the requirements of state language regulation committee.

\section{Concluding remarks}

Collocations, idioms, phrasal verbs, proper names and other fixed sets may be taken as formulaic language sequences for analysis in various types of discourse. As the results of the research demonstrate sometimes the translation assignments of such origin may be a challenge to the translator when there are no equivalents or literal translation could not be performed, so various translation strategies should be considered in order to transfer the text to the source language while presenting it not only textually but also maintaining its connotative meanings and other features in accordance with the target culture. The analysis indicates that the paraphrasing when using related or unrelated words was applied on most of the instances where a particular translation strategy was employed. It may be due to the fact that the source and the target languages have lexical differences and the collocational environments are particularly distinctive. When translating idioms, most of them were also translated literally or replaced by an equivalent as well as there was a considerable number of translation strategies applied on idioms and idiomatic expressions. Some of the cases revealed that idioms with propositional meanings made some difficulties to the translator whether they were misinterpreted or translated literally without considering their referential or emotive meanings.

\section{References:}

1. Baker, M. (1992). In Other Words. New York: Routledge.

2. Bassnett-McGuire, S. (1980) Translation studies. London and New York: Methuen.

3. Heid, U. (2001). Collocations in Sublanguage Texts: Extraction from Corpora. Handbook of Terminology Management, Volume 2: 
Application Oriented Terminology Management. (pp.788-808). Amsterdam: John Benjamins Pub.

4. Hsu, W. (2014). The most frequent opaque formulaic sequences in English-medium college textbooks. System, 47, 146-161. doi:10.1016/j.system.2014.10.001

5. Manning, Ch. \& Schutze, H. (1999). Foundations of Statistical Natural Language Processing. London: The MIT Press Cambridge.

6. Moon, R. (2011). Vocabulary connections: multi-word items in English. In N. Schmitt (ed.) Vocabulary: Description, Acquisition and Pedagogy (pp.40-63). Cambridge: Cambridge University Press.

7. Newmark, P. (1988). A Textbook of Translation. New York: Prentice Hall.

8. Schmitt, N. (2004). Formulaic Sequences. Amsterdam: John Benjamins Pub.

9. Wood, D. (2010). Perspectives on Formulaic Language. London: Bloomsbury Pub.

10. Wray, A. (2002). Formulaic Language and the Lexicon. Cambridge: Cambridge University Press.

11. Wright, S., Leland D. (1993). Scientific and Technical Translation. Amsterdam: John Benjamins Pub 